ISSN: 2638-6062

\title{
Born with Teeth
}

\author{
Xavier Riaud* \\ Department of Dental Surgery, France
}

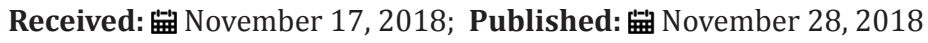

*Corresponding author: Xavier Riaud, History of Sciences and Technics, Department of Dental Surgery, 145, route de Vannes, 44800 Saint Herblain, France

\section{Opinion}

Such structures have been described by Titus Livius in cuneiform written texts in 59 B.C. In 23 B.C. Caius Plinius Secundus the Elder thought that boys born with teeth were likely to have a bright future, while on the contrary, girls with natal teeth (= name given to those structures) were likely to live a disastrous life. Are said to be born with teeth: Hannibal, Robertus Diabolus, Richard III of England, Carlos Prince of Asturias, ill-fated son of Philip II of Spain, Mazarin, Louis XIII of France, Louis XIV of France, Mozart, Mirabeau, Danton, Napoleon, Loulou, son of Napoleon III. Following that train of thought, allusions can be found in famous literary works, like in Shakespeare's Richard III (1623), as shown in the following extracts: "[...] they say my uncle grew so fast that he could gnaw on a crust at two hours old [...]" or "[...] a hellhound [Richard III] [...] that had his teeth before his eyes [...]" Henri IV of France is said to have been born with teeth. "As soon as Henri IV was born, his grandfather rubbed his lips with garlic and put a drop of wine in his mouth." The child is said to have had eight successive nurses, which is one less than Louis XIV of France.

When he was born, it seemed like the young Louis was gifted with teeth. In a 1638 letter to Oxenstierna, the famous jurist from the Dutch Republic (former Netherlands), Hugo Grotius, testifies how ravenous the child was and the pain of the nurses bitten by the small toothed dauphin. It seemed to be two maxillary central incisors. "Everybody was astonished when Anne of Austria, after twenty years of sterility, gave birth to a prince who already had two teeth. Many times the nurse had to be changed, for the ravenous dauphin was sinking his teeth... into their breast. One of the royal officials complained a lot because of the bites of the baby lion. Her name was Perrette, or Pierrette Dufour; after repetitive bites from the toddler, she suffered from hardness in her udder, which forced her to interrupt breastfeeding, for at least a few days. Her Majesty the Queen Mother only had to touch the inconvenienced parts with a relic to make the pain and the hardness disappear; the nurse could then continue to breastfeed her noble infant." Pierrette continued to breastfeed until needed, that is to say for two years.

Three months after his birth, he had got as far as three nurses. "Those who had not Milk enough," according to the writings of the surgeon Dionis, "he bit their Nipples, even till the Blood came." From January 1639, he had exhausted nine nurses. In August, Grotius wrote from Paris to van Baerle (1584-1648), a Dutch geographer and theologian: "The dauphin would not limit himself to dry up his nurses, he would tear them with his bites. It's France's neighbours that have to mistrust such a precocious voracity." For Mirabeau, his birth was surrounded by a legend, highly questionable. "A turbulent pregnancy and the supernatural dimension of the child's head put the mother in the greatest danger. The size and vigor of the newborn were unprecedented, and two molars were already formed in his mouth." "He was born with a twisted foot, two big teeth and a huge head above all. He also had his tongue tied by the web. Before presenting the child to his father, the nanny warned him: "Do not be afraid." And the obstetrician added, "He will have a hard time expressing himself [1].

\section{References}

1. Riaud X (2011) Chroniques odontologiques des rois de France et de la dynastie napoléonienne [Odontological chronicles of the kings of France and of the Napoleon dynasty]. Paris: L'Harmattan, Collection Médecine à travers les siècles [Medicine throughout centuries collection] pp. 289. 
(c) (i) This work is licensed under Creative

To Submit Your Article Click Here: Submit Article

DOI: $10.32474 /$ PRJFGS.2018.02.000147

\begin{tabular}{|c|c|}
\hline PRJFGS & $\begin{array}{l}\text { Peer Reviewed Journal of Forensic } \\
\text { \& Genetic Sciences }\end{array}$ \\
\hline & $\begin{array}{l}\text { Assets of Publishing with us } \\
\text { - Global archiving of articles } \\
\text { - Immediate, unrestricted online access } \\
\text { - } \quad \text { Rigorous Peer Review Process }\end{array}$ \\
\hline 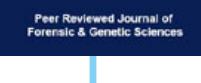 & $\begin{array}{l}\text { - Authors Retain Copyrights } \\
\text { - Unique DOI for all articles }\end{array}$ \\
\hline
\end{tabular}

